\title{
MEDIA PEMBELAJARAN POHON KLASIFIKASI DAPAT MENINGKATKAN HASIL BELAJAR SISWA
}

\author{
Zaharah, zaharahzaharah40@gmail.com \\ Tri harjawati@uinjkt.ac.id \\ Imam Wahyudi: imayudi.77@gmail.com \\ Cut dhien nurwahidah .@uinjkt.ac.id. \\ (Dosen Fakultas Ilmu Tarbiyah dan Keguruan UIN Syarif Hidayatullah Jakarta)
}

\begin{abstract}
Abstrak:
Peningkatan hasil belajar IPS mata pelajaran geografi penggunaan Pohon Klasifikasi, metode pembelajaran Cooperative learning dan Jigsaw, teknik yang digunakan adalah kelompok diskusi dalam IIS B kelas XI di 58 Sekolah Menengah Atas Negeri Jakarta. Dapat disimpulkan menurut data analitik dari Post Test Cycle I dengan median 72, 0588 atau 72\%, dengan kategori Sukses atau Tidak Sukses, pada Siklus II dengan median 85, 2941 atau 85, $2 \%$, dengan Bagus/kategori Sangat Sukses. Dengan demikian, nilai rata-rata memenuhi nilai standar KKM ditetapkan menjadi 75. Berdasarkan ini; dapat dikatakan bahwa ada peningkatan hasil belajar dengan metode Klasifikasi Pohon.
\end{abstract}

\section{Kata Kunci: Media Pembelajaran, Pohon, Hasil Belajar Siswa.}

\section{A. Pendahuluan}

Pendidikan dikalangan masyarakat luas dianggap menjadi sebuah hal penting bahkan wajib dalam kehidupannya, pendidikan kini bukan hanya menjadi urusan pribadi namun menjadi urusan negara atau nasional. Negara Republik Indonesia mengatur dan memfasilitasi segala sesuatu yang berurusan dengan pendidikan dalam negeri ini.

Proses belajar mengajar disekolah terjadi antara guru dan siswa dalam kegiatan apapun di sekolah baik dalam proses belajar mengajar maupun tidak dalam proses belajar mengajar. Pesan yang akan dikomunikasikan adalah isi ajaran ataupun didikasi yang ada dalam kurikulum, sumber pesannya bisa guru, siswa, orang lain ataupun penulis buku atau prosedur media. Pesan berupa isi ajaran dan didikan yang ada di kurikulum tersebut di tuangkan oleh guru ke dalam simbol-simbol komunikasi verbal maupun non verbal (visual).
Dalam proses pembelajaran, kehadiran media pembelajaran mempunyai arti yang cukup penting. Karena dalam kegiatan tersebut ketidakjelasan bahan yang disampaikan dapat di bantu dengan menghadirkan media sebagai perantara. Keunikan bahan yang akan di sampaikan kepada siswa dapat diselenggarakan dengan bantuan media. Penggunaan media pembelajaran di sekolah SMA Negeri 58 Jakarta masih sedikit digunakan dalam proses pembelajaran di kelas, karena guru lebih suka memakai metode konvesional dan pemberian tugas kepada murid di kelas daripada menggunakan media pembelajaran pada proses pembelajaran.

Media harusnya dapat mewakili apa yang guru kurang mampu ucapkan melalui kalimat-kalimat tertentu. Bahkan keabstrakan bahan ajar dapat di konkritkan dengan kehadiran media, dengan demikian anak didik akan lebih mudah untuk mencerna bahan ajar dari pada tanpa bantuan media. Menurut Yudhi Munadi: 
Perluasaan konotasi media menjadi sarana pembelajaran tidak semata berkonotasi media penyampaian dan komunikasi pengajaran, tetapi juga sebagai sumber belajar bagi para siswa dalam melakukan aktivitas pembelajaran, serta dalam eksplorasi informasi pengetahuan.

Aspek penting lainnya penggunaan media adalah membantu memperjelas pesan pembelajaran. Informasi yang disampaikan secara lisan terkadang tidak dipahami sepenuhnya oleh siswa, terlebih apabila guru kurang cakap dalam memperjelas materi. Disinilah peran media, sebagai alat bantu memperjelas pesan pembelajaran.

Dari sekian banyak media yang digunakan dalam pengajaran, penulis tertarik untuk memilih media Pohon Klasifikasi (Bagan Pohon) sebagai media pengajaran IPS khususnya pada bidang Geografi. Mengapa harus Bagan Pohon? Karena dengan menggunakan Bagan Pohon semua siswa dapat menarik perhatian mereka untuk melihat Bagan Pohon tersebut dan mengidentifikasikan bagaimana gambaran akan Bagan Pohon tersebut. Siswa akan lebih tertarik untuk terlebih dahulu melihat bagaimana Bagan Pohon yang berwarna-warni dan kemudian melihat kedalam penjelasan dibandingkan dengan buku yang berikan tulisan saja, tentu hal ini di anggap kurang menarik.

Dari hasil observasi yang peneliti lakukan sebelum melakukan penelitian terdapat banyak objek yang peneliti bisa teliti, diantaranya: (1) Guru-guru yang mengajar mata pelajaran khususnya pelajaran geografi masih kurangnya mamanfaatkan media dalam menyampaikan materi dikelas. (2) Guru mata pelajaran Geografi dalam menyampaikan materi dikelas hanya menyampaikan materi dengan tugas dan presentasi serta menggunakan metode konvesional. (3) Nilai yang diperoleh siswa dalam mata pelajaran Geografi masih ada yang dibawah standar KKM.

\section{B. Acuan Teori Area dan Fokus Yang Diteliti}

\section{Pengertian Hasil Belajar}

Menurut Nana Sudjana "Hasil belajar adalah kemampuan-kemanpuan yang dimiliki siswa setelah ia menerima pengalaman belajarnya".

Menurut Gagne, ada beberapa tujuan dari hasil belajar: (1) Informasi verbal; yaitu penguasaan informasi dalam bentuk verbal, baik secara tertulis maupun tulisan, misalnya pemberian nama-nama terhadap suatu benda, definisi, dan sebagainya. (2) Kecakapan intelektual; yaitu keterampilan individu dalam melakukan interaksi dengan lingkungannya dengan menggunakan simbol-simbol, misalnya: penggunaan simbol matematika. Termasuk dalam keterampilan intelektual adalah kecakapan dalam membedakan (discrimination), memahami konsep konkret, konsep abstrak, aturan dan hukum. Keterampilan ini sangat dibutuhkan dalam menghadapi pemecahan masalah. (3) Strategi kognitif; kecakapan individu untuk melakukan pengendalian dan pengelolaan keseluruhan aktivitasnya. Dalam konteks proses pembelajaran, strategi kognitif yaitu kemampuan mengendalikan ingatan dan cara-cara berfikir agar terjadi aktivitas yang efektif. Kecakapan intelektual menitikberatkan pada hasil pembelajaran, sedangkan strategi kognitif lebih menekankan pada proses pemikiran. (4) Sikap; yaitu hasil pembelajaran yang berupa kecakapan individu untuk memilih macam tindakan yang dilakukan. Dengan kata lain, sikap adalah keadaan dalam diri individu yang akan memberikan 
kecenderungan bertindak dalam menghadapi suatu objek atau peristiwa, di alamnya terdapat unsur pemikiran, perasaan yang menyertai pemikiran dan kesiapan untuk bertindak. (5) Keterampilan motoris; ialah hasil belajar yang berupa kecakapan pergerakan yang dikontrol oleh otot dan fisik.

Dari paparan diatas sangat jelas bahwa hasil dari proses pembelajaran harus menghasilkan suatu input yang positif didalam diri seorang siswa yang sudah mendapat teori-teori yang disampaikan oleh guru disekolah. Didalam bersosialisasi manusia harus mempunyai karakter yang bisa diterima oleh masyarakat sekitar, oleh karena itu wawasan yang luas terhadap kecakapan-kecapan intelektual, sikap dan motorik sangat diperlukan dalam kita bersosialisasi.

\section{Pengertian Penilaian}

Menurut Nana Sudjana Penilaian hasil belajar adalah proses pemberian nilai terhadap hasil-hasil belajar yang dicapai siswa dengan kriteria tertentu. Hal ini mengisyaratkan bahwa objek yang dinilainya adalah hasil belajar siswa. Hasil belajar siswa pada hakikatnya adalah perubahan tingkah laku seperti telah dijelaskan di muka. Tingkah laku sebagai hasil belajar dalam pengertian yang luas mencakup bidang kognitif, afektif, dan psikomotoris. Oleh sebab itu, dalam penilaian hasil belajar, peranan tujuan instruksional yang berisi rumusan kemampuan dan tingkah laku yang diinginkan dikuasai siswa menjadi unsur penting sebagai dasar dan acuan penilaian.

\section{Pengertian Media Pembelajaran}

Kata "media" berasal dari kata latin, merupakan bentuk jamak dari kata medium. Secara harfiah kata tersebut mempunyai arti perantara atau pengantar.Akan tetapi sekarang kata tersebut digunakan, baik untuk bentuk jamak maupun mufrad. Jadi, Media merupakan alat bantu yang sangat bermanfaat bagi para siswa dan pendidik dalam proses belajar dan mengajar. Dengan adanya media pengajaran, peran guru menjadi semakin luas. Sedangkan anak didik akan terbantu untuk belajar dengan lebih baik, serta terangsang untuk memahami subjek yang tengah diajarkan dalam bentuk komunikasi penyampaian pesan yang lebih efektif dan efisien.

Dengan demikian, pembelajaran merupakan hubungan timbal balik antara guru (pemberi informasi) dan peserta didik (penerima informasi). Hubungan timbal balik tersebut dapat dilakukan dengan cara komunikasi. Selain dengan komunikasi verbal, seorang guru juga dapat menggunakan media pembelajaran sebagai alat bantu untuk memperkuat komunikasi dengan peserta didik.

\section{Fungsi, Manfaat dan Kegunaan Media Pembelajaran}

Ada beberapa fungsi media pembelajaran dalam pembelajaran, di antaranya: (1) Sebagai alat bantu dalam proses pembelajaran, (2) Sebagai komponen dari sub sistem pembelajaran, (3) Sebagai pengarah dalam pembelajaran, (4) Sebagai permainan atau membangkitkan perhatian dan motivasi siswa, (5) Meningkatkan hasil dan proses pembelajaran, (6) Mengurangi terjadinya verbalisme, (7) Mengatasi keterbatasan ruang, waktu tenaga dan daya indra.

Secara umum media mempunyai kegunaan: (1) Memperjelas pesan agar tidak terlalu verbalistis, (2) Mengatasi keterbatasan ruang, waktu tenaga dan daya indera, (3) Menimbulkan gairah belajar, 
interaksi lebih langsung antara murid dengan sumber belajar, (4) Memungkinkan anak belajar mandiri sesuai dengan bakat dan kemampuan visual, auditori dan kinestetiknya, (5) Memberi rangsangan yang sama, mempersamakan pengalaman dan menimbulkan persepsi yang sama.

Manfaat media pembelajaran dalam proses pembelajaran adalah sebagai berikut: (1) Pembelajaran akan lebih menarik perhatian siswa sehingga dapat menumbuhkan motivasi belajar, (2) Materi pembelajaran akan lebih jelas maknanya sehingga dapat lebih dipahami oleh para siswa dan memungkinkan siswa menguasai tujuan pembelajaran lebih baik, (3) Metode pembelajaran akan lebih bervariasi, tidak semata-mata komunikasi verbal melalui penuturan kata-kata oleh guru, sehingga siswa tidak bosan dan guru tidak kehabisan tenaga, apalagi bila guru harus mengajar untuk setiap jam pelajaran, (4) Siswa lebih banyak melakukan kegiatan belajar, sebab tidak hanya mendengarkan uraian guru, tetapi juga aktivitas lain seperti mengamati, melakukan, mendemonstrasikan, dan lain-lain.

\section{Pengertian Ilmu Geografi}

Pengertian Geografi adalah ilmu yang mempelajari mengenai lokasi serta persamaan dan perbedaan (variasi) keruangan, lingkungan dan kompleks wilayah atas fenomena fisik, makhluk hidup dan manusia di atas permukaan bumi.

\section{Landasan Media Pohon Klasifikasi a. Bagan}

Bagan adalah sama dengan diagram, bedanya, bagan lebih menekankan kepada salah satu pengembangan, ada kalanya disertai dengan simbol atau gambar, maka sifatnya pictorial, dan ada juga bagan yang ditambahkan keterangan singkat.Fungsi media bagan yang paling pokok adalah manyajikan ide-ide atau konsep-konsep yang sulit bila hanya disampaikan secara tertulis atau lisan secara visual. Bagan juga mampu memberikan ringkasan butir-butir penting dari suatu presentasi.

\section{b. Mind Mapping}

Mind Map adalah "alternatif pemikiran keseluruhan otak pada pemikiran linear". Kata mind mapping berasal dari bahas inggris yaitu mind yang artinya pikiran dan map adalah peta.secara harfiaah mind mapping diartikan sebagai peta pikiran, yaito sistem pemetaan yang dilakukan oleh pikiran manusia.

Tony Buzan mengemukakan bahwa mind map akan memberi pandangan menyeluruh pada pokok masalah atau area yang luas, Selain itu juga, memungkinkan kita merencanakan rute atau membuat pilihan-pilihan dan mengetahui ke mana kita akan pergi dan di mana kita berada, begitu juga dapat mengumpulkan sejumlah besar data di satu tempat. Serta dapat mendorong pemecahan masalah dengan membiarkan kita melihat jalan-jalan terobosan kreatif baru. Mind map juga tentunya menyenangkan untuk dilihat, dibaca, dicerna dan di ingat. Mind map juga merupakan peta pemikiran yang hebat ingatan, memungkinkan kita menyusun pikiran sedemikian rupa sehingga kara kerja otak dilibatkan sejak awal. Ini berarti mengingat informasi akan lebih mudahdan lebih bisa diandalkan daripada menggunakan teknik pencacatan tradisional.

\section{Pohon Klasifikasi Sebagai Media Pembelajaran}

Pohon klasifikasi adalah suatu media pembelajaran membantu guru untuk memberikan penjelasan yang lebih 
mendetail mengenai materi Potensi Geografis Indoneia. Media pohon klasifikasi dibuat dengan maksud meningkatkan perhatian dan supaya siswa lebih tertarik terhadap pokok bahasan Potensi Geografis Indonesia.

\section{Metodologi Penelitian}

\section{Tempat dan Waktu Penelitian}

Penelitian dilakukan di SMA Negeri 58 Jakarta yang beralamat di Jalan Raya Ciracas No. 2 Kel. Ciracas Jakarta Timur. Penelitian ini dilaksanakan pada bulan Agustus 2015 sampai dengan Desember 2015 semester Ganjil tahun pelajaran 2015/2016.

\section{Pendekatan dan Metode Penelitian}

Metode penelitian yang digunakan adalah metode penelitian tindakan kelas. Penelitian Tindakan Kelas (PTK) adalah penelitian tindakan (action research).

\section{Teknik Pengumpulan Data \\ a. Sumber Data}

Sumber data diperoleh dari siswa kelas XI IIS B SMA Negeri 58 Jakarta tahun ajaran 2015/2016. Data yang diperoleh dari hasil penelitian berupa peningkatan hasil belajar IPS khususnya mata pelajaran Geografi pada kemampuan kognitif, lembar observasi, dan lembar wawancara.

\section{b. Pengumpulan Data}

Instrumen pengumpulan data yang digunakan dalam penelitian ini terdiri dari lembar observasi, pedoman wawancara, tes hasil belajar. Berikut penjelasan masingmasing.

1) Lembar Observasi

Lembar observasi digunakan untuk mengevaluasi kegiatan mengajar peneliti selama tindakan pada siklus I dan siklus II.

2) Wawancara dengan Guru dan Siswa
Menurut Esterberg mendefinisikan interview sebagai berikut, "a meeting of two persons to exchange information and idea trought question and response, resulting in communication and join construction of meaning abaut a particular topic". Wawancara merupakan pertemuan dua orang untuk bertukar infirmasi dan ide melalui Tanya jawab, sehinga dapat dikonstruksikan makna dalam suatu topik tertentu. Wawancara dilakukan untuk mengetahui tanggapan dan kesan guru atau subyek terhadap kegiatan tindakan pada siklus I dan siklus II dengan menggunakan pedoman wawancara. Wawancara juga digunakan untuk mengetahui gambaran umum proses pembelajaran dan masalahmasalah pada tindakan siklus I dan II.

\section{Teknik Analisis Data}

Untuk mengolah dan menganalisa hasil data penelitian yang telah terkumpul dari narasumber terkait, dilakukan tiga langkah yaitu sebagai berikut:

a. Mengumpulkan soal untuk di uji di kelas sesuai dengan materi yang di teliti.

b. Melakukan validasi soal yang telah di kerjakan siswa dan menggunakan perhitungan dengan menggunakan Anates.

c. Menyaring soal yang ingin di kerjakan untuk para siswa yang di teliti

d. Melakukan N-Gain

Menurut Meltzer untuk mengetahui peningkatan skor pre tes dan post test menggunakan rumus Normalized Gain.

Indeks Gain $=\frac{\text { skor tesakhir }- \text { skor tesaw al }}{\text { skorideal }- \text { skor tesaw al }}$

\section{Hasil Penelitian}

1. Sejaran Sekolah

SMA Negeri 58 Jakarta berdiri di wilayah Jakarta Timur, tepatnya di Jalan 
Raya Ciracas, Kelurahan Ciracas, Kecamatan Ciracas, Jakarta Timur. SMA Negeri 58 Jakarta merupakan Kelas Jauh (KJ) SMA Negeri 8 Jakarta, didirikan tahun 1979.

Visi: Unggul dalam Bidang Imtaq, Iptek dan Berkarakter Bangsa di Era Global, Misi: (1) Meningkatkan Kualitas Sumber Daya Manusia, (2) Meningkatkan kualitas pembelajaran dan pelayanan Pendidikan, (3) Meningkatkan Penerapan Pendidikan Karakter, (4) Meningkatkan Kemampuan Berbahasa Inggris dan IT dalam Pembelajaran, (5) Meningkatkan Sarana dan Prasarana, (6) Meningkatkan kerjasama dengan pihak terkait, (7) Menerapkan Ilmu dan Akhlak Mulia dalam Kehidupan.

\section{Deskripsi Data Hasil Pengamatan/ Hasil Intervensi Tindakan}

Subjek penelitian ini adalah siswa/i SMA Negeri 58 Jakarta kelas XI IIS B sebanyak 34 siswa yang terdiri dari 10 laki-laki dan 24 perempuan siswa/i. Berdasarkan hasil observasi, melalui pengamatan langsung di kelas XI IIS B.

\section{- Siklus I}

Pertemuan pertama (Senin, 12 Oktober 2015), Proses pembelajaran diawali dengan memberi salam, berdoa, dan mengabsen siswa. Selanjutnya dengan apersepsi yang dilakukan oleh guru, tujuan untuk merangsang siswa agar berfikir mengenai materi yang akan dipelajari. Setelah siswa berfikir, menjawab pertanyaan yang diajukan guru atau mengungkapkan pendapatnya kemudian guru menyampaikan tujuan dari pembelajaran. Selanjutnya guru memberikan soal Pre Test kepada siswa tujuannya adalah untuk mengukur seberapa jauh siswa telah memiliki kemampuan mengenai hal-hal yang akan dipelajari.
Selanjutnya guru menjelaskan materi mengenai luas dan batas territorial Negara Indonesia dan potensi fisik penduduk Indonesia (selama 60-90 menit), dengan menggunakan model pembelajaran Problem Based Learning (PBL). Setelah itu siswa dibagi menjadi beberapa kelompok, dalam satu kelompok terdiri dari 5-6 orang, setelah pembagian kelompok, selanjutnya guru menjelaskan langkah-langkah model pembelajaran Problem Based Learning (PBL), masingmasing kelompok harus berbentuk lingaran, setelah itu guru memberikan selembaran kertas kepada semua kelompok untuk mencatat informasi tenatang meteri yang diberikan oleh guru. Masing-masing kelompok mendapatkan waktu 10-15 menit untuk mencatat informasi pembelajaran. Selama proses pembelajaran berlangsung, peneliti bertindak sebagai guru pengajar dan guru bidang studi bertindak sebagai observer yang mengamati aktivitas siswa, aktivitas guru, serta kegiatan proses pembelajaran.

Pertemuan ke dua (Senin, 19 Oktober 2015), Diawali dengan memberi salam, berdoa, mengabsen siswa dan apersepsi. Selanjutnya guru langsung menyuruh siswa kumpul dengan kelompok yang baru dan guru memberikan selembaran pertanyaan tentang materi pembelajaran yang sudah dilaksanakan di pertemuan pertama dengan menggunakan media pembelajaran. Jika dalam pertemuan pertama siswa dibuat kelompok dan guru memberikan materi yang akan di diskusikan dan dipresentasikan didepan kelas, dan di pertemuan kedua siswa dibuat kelompok yang sama dan diberikan materi Potensi Sosial Penduduk Indonesia terkait dengan luas dan batas Negara Indonesia serta potensi fisik pendduk Indonesia. dan kelompok-kelompok tersebut diberikan 
masalah mengenai materi potensi fisik dan sosial penduduk Indonesia. Setalah semuanya dilaksankan guru beserta siswa menyimpulkan hasil pembelajaran. Proses pembelajaran pada siklus I diakhiri dengan melakukan Post Tes, tujuannya untuk mengukur apakah siswa telah menguasai materi pembelajaran yang sudah diajarka.

\section{Hasil Pengamatan Siklus I}

Rekapitulasi $N$ - Gain Siklus I

\begin{tabular}{|c|c|c|c|}
\hline No & $\boldsymbol{N}$ - Gain & $\begin{array}{c}\text { Kriteria } \\
\boldsymbol{N} \text { - Gain }\end{array}$ & Jumlah \\
\hline 1 & Nilai $(\mathrm{g}) \geq 0,7$ & Tinggi & \\
\hline 2 & $\begin{array}{c}\text { Nilai } 0,7>(\mathrm{g}) \geq \\
0,3\end{array}$ & Sedang & 14 \\
\hline 3 & Nilai $(\mathrm{g})<0,3$ & Rendah & 20 \\
\hline \multicolumn{3}{|c|}{ Jumlah } & $\mathbf{3 4}$ \\
\hline
\end{tabular}

Dari tabel di atas untuk hasil belajar siklus I diperoleh nilai $N$-gain sedang sejumlah 14 orang, dan yang memperoleh $N$-gain rendah sejumlah 20 orang. Bisa dilihat banyaknya yang memperoleh nilai $N$-gain rendah hampir $58 \%$. Ini menunjukan media pembelajaran Pohon Klasifikasi masih belum efektif untuk meningkatkan hasil belajar siswa.

\section{- Siklus II}

Pertemuan pertama (Senin, 26 Oktober 2015), Proses pembelajaran diawali dengan guru mengkondisikan situasi pembelajaran dan kesiapan siswa dalam mengikuti proses pembelajaran kemuadian memberi salam, berdoa, dan mengabsen siswa serta guru memberikan motivasi dan apersepsi kepada siswa. Dilanjutkan dengan guru memberikan soal Pre Test kepada siswa, guru menyampaikan indikator bahasan yang akan dipelajari siswa, guru menjelaskan materi mengenai potensi geografis Indonesia untuk ketahanan pangan dan potensi geografis Indonesia untuk penyediaan lahan industri dan metode yang digunakan adalah sama dengan siklus yang pertama atau Problem Based Learning (PBL). Selanjutnya guru memberikan kesempatan kepada siswa untuk bertanya dan mengungkapkan pendapatnya. Pada pertemuan pertama guru ataupun siswa mengakhiri pembelajaran dengan menyimpulkan pembelajaran mengenai meteri potensi geografis Indonesia untuk ketahanan pangan, potensi geografis Indonesia untuk penyediaan lahan industri.

Pertemuan kedua (Senin, 2 November 2015), Pada kegiatan awal pertemuan ini diawali dengan memberi salam, berdoa, mengabsen siswa dan apersepsi. Selanjutnya guru menjelaskan langkah-langkah media pembelajaran Pohon Klasifikasi dengan materi potensi geografis Indonesia untuk energi alternatif. Setelah itu guru membagi siswa menjadi 6 kelompok, dalam satu kelompok terdiri 6 orang siswa dibagi secara acak. setelah pembagian kelompok, masing-masing kelompok harus berbentuk lingkaran, setelah itu guru menjelaskan cara berdiskusi dengan menggunakan metode Kooperatif Learning Tipe Jugsaw di mana siswa berdiskusi dengan materi yang telah diberikan oleh guru yang berbeda-beda setiap kelompoknya dan setelah kelompok diskusi lalu semua anggota kelompok berpencar kekelompok yang lainnya sampai satu kelompok yang baru tersebut mempunyai perwakilan anggota kelompok 1 sampai anggota kelompok 6. Lalu perwakilan anggota masing-masing memberikan informasi kepada temannya dari kelompok lainnya, setelah dikira sudah cukup semua anggota kelompok mendapatkan informasi lain dari informan lain, dan selanjutnya para siswa diminta untuk kembali kekelompok awal. Guru mengamati dan membimbing siswa kepada 
setiap kelompok selama proses pembelajaran. Kemudian siswa mempresentasikan, guru bersama siswa menyimpulkan hasil pembelajaran. Proses pembelajarn siklus II ini berakhir dengan memberikan Post Test kepada siswa terkait materi pembelajaran yang sudah dibahas.

\section{Hasil Pengamatan Siklus II}

Rekapitulasi N- Gain Siklus II

\begin{tabular}{|c|c|c|c|}
\hline No & N - Gain & $\begin{array}{c}\text { Kriteria N- } \\
\text { Gain }\end{array}$ & Jumlah \\
\hline 1 & Nilai $(\mathrm{g}) \geq 0,7$ & Tinggi & 3 \\
\hline 2 & $\begin{array}{c}\text { Nilai } 0,7>(\mathrm{g}) \\
\geq 0,3\end{array}$ & Sedang & 27 \\
\hline 3 & Nilai $(\mathrm{g})<0,3$ & Rendah & 4 \\
\hline \multicolumn{3}{|c|}{ Jumlah } & $\mathbf{3 4}$ \\
\hline \multicolumn{3}{|c|}{ Untuk hasil belajar siklus II }
\end{tabular}

diperoleh rata-rata $N$-gain sebesar $0,46$. Jumlah siswa yang mendapatkan Nilai $N$ gain tinggi 3 orang, jumlah siswa yang mendapatkan $N$-gain sedang sebanyak 27 orang, dan jumlah siswa yang mendapakan $N$-gain rendah 4 orang.

\section{Pembahasan Hasil Penelitian}

Proses pembelajaran yang dilakukan penelitian ini adalah siswa kelas X1 IIS B SMA Negeri 58 Jakarta adalah menerapkan media pembelajaran Pohon Klasifikasi dengan beberapa model pembelajaran yang berbeda yaitu dengan model pembelajaran Problem Based Learning (PBL) pada siklus I dan model pembelajaran Problem Based Learning $(P B L)$ dan Kooperatif Learning tipe Jigsaw pada siklus II. Sebelum dilakukan tindakan pembelajaran dengan menerapkan media pembelajaran Pohon Klasifikasi, proses pembelajaran IPS khususnya pelajaran Geografi adalah melakukan observasi kelas dan mengikuti guru pamong yang sedang memberikan materi pelajaran Geografi.
Sehingga siswa kurang aktif selama proses pembelajaran berlangsung.

Media pembelajaran Pohon Klasifikasi adalah penelitian yang dilakukan di kelas dengan tujuan memperbaiki atau meningkatkan mutu hasil pembelajaran. Dengan lebih menekankan pada proses pembelajaran pada siswa agar lebih menguasai materi pelajaran dan berhasil pada hasil belajar yang berupa tes kognitif. Penerapan media pembelajaran Pohon Klasifikasi terdiri dari beberapa tahap yaitu: Perencanaan (Planning), Tindakan (Acting), Pengamatan (Observing), dan Refleksi (Reflecting). Hasil pengamatan melalui lembar observasi dan hasil wawancara dengan guru dan siswa pada penelitian ini menunjukkan bahwa siswa menyenangi proses pembelajaran IPS khususnya pelajaran Geografi melalui penerapan media pembelajaran Pohon Klasifikasi. Penerapan media pembelajaran Pohon Klasifikasi dapat meningkatkan gambaran terhadap materi yang diberikan oleh siswa. Berdasarkan pengamatan selama berlangsungnya pembelajaran dengan menggunakan media pembelajaran Pohon Klasifikasi ini siswa menjadi lebih aktif karena diharuskan berdiskusi dengan anggota kelompoknya untuk membahas materi yang diberikan oleh peneliti. Siswa juga dapat bertukar pikiran antara anggota kelompok lain. Sehingga penerapan media pembelajaran Pohon Klasifikasi dapat meningkatkan hasil belajar siswa.

Penilaian banyak bentuknya baik berupa tes tertulis dan tidak tertulis. Peneliti melakukan evaluasi pembelajaran dengan menggunakan tes tertulis dengan jumlah persiklus 20 soal. Berdasarkan hasil tes yang dilaksanakan pada siklus I diperoleh nilai paling rendah yang diperoleh siswa pada saat Pretest adalah 40 
dan nilai tertinggi pada saat Pretest adalah 80 dengan nilai rata-rata nilai Pretest 60,5882. Masih banyak siswa yang mendapatkan nilai di bawah KKM 75. Sedangkan nilai terendah yang diperoleh siswa pada saat Postest sebesar 55, sedangkan nilai tertinggi pada skor Postest sebesar 85 dengan rata-rata nilai Postest 72,0588 juga masih ada siswa di bawah nilai KKM. Walaupun ada yang mendapat nilai 85 hampir sebagian siswa yang masih di bawah nilai KKM yaitu 75. Untuk hasil belajar siklus I diperoleh rata-rata $\mathrm{N}$-gain sebesar 0,28 Dari hasil tes yang diperoleh diketahui ketuntasan siswa belum maksimal. Ini berarti penerapan media pembelajaran Pohon Klasifikasi yang digunakan belum efektif dalam meningkatkan hasil belajar sesuai dengan standar $N$-gain.

Dengan demikian indikator keberhasilan penelitian ini belum tercapai, sehingga diperlukan penyempurnaan untuk masing-masing nilai siswa dan peneliti melanjutkan ke siklus II mencoba memperbaiki dan menyempurnakan dari kekurangan yang terdapat di siklus I. Berdasarkan hasil observasi siklus I aktifitas siswa belum memuaskan. Hal ini terlihat dari kurangnya komunikasi dalam kelompok, sebagian besar kelompok masih mengandalkan siswa yang pintar untuk mengerjakan tugas, masih sedikitnya jumlah siswa yang bertanya maupun yang menjawab pertanyaan, serta munculnya rasa bosan siswa dalam kegiatan proses pembelajaran.

Untuk mengatasi kekurangankekurangan yang terjadi pada siklus I, guru melakukan perbaikan yang dilaksanakan pada siklus II. Hasil belajar siswa pada siklus II yaitu nilai paling rendah yang diperoleh siswa pada saat Pretest adalah 60 dan nilai tertinggi pada saat Pretest adalah
90 dengan nilai rata-rata Pretest 73,6764. Masih ada siswa di bawah nilai KKM yaitu 75. Sedangkan nilai terendah pada saat Postest sebesar 75, dan skor Postest sebesar 95 dengan nilai rata-rata Postest 85,2941. Sudah semua siswa yang mendapat nilai di atas nilai KKM 75. Ini menunjukkan ketuntasan siswa mencapai $100 \%$ pada siklus II. Untuk hasil belajar siklus II diperoleh rata-rata $N$ - gain sebesar 0,45 .

Keberhasilan belajar seseorang juga dipengaruhi oleh keterampilanketerampilan yang dimilikinya, seperti keterampilan membaca, berdiskusi, memecahkan masalah, mengerjakan tugastugas dll.

Berdasarkan hasil observasi dan evaluasi, dapat dikatakan bahwa jalannya pembelajaran pada siklus II telah berhasil memperbaiki berbagai kelemahan yang terjadi pada siklus I. Perbaikan tersebut menimbulkan peningkatan hasil belajar siswa yang memuaskan. Siswa memberikan respon yang positif terhadap media pembelajaran Pohon Klasifikasi yang diterapkan pada siklus II, karena siswa dapat berusaha untuk menggali dan mendalami materi belajar yang disampaikan oleh guru. Siswa saling membantu dalam memahami materi yang diajarkan. Media pembelajaran Pohon Klasifikasi dengan berbagai macam model pembelajaran yang diterapkan pada siklus I dan II yaitu model pembelajaran Problem Based Learning (PBL) dan Kooperatif Learning tipe Jigsaw dapat menumbuhkan kerjasama dan tanggung jawab siswa. Berikut diberikan grafik perbandingan hasil penelitian siklus I terhadap siklus II. 
4. Perbandingan Hasil Penelitian Siklus I dan Siklus II

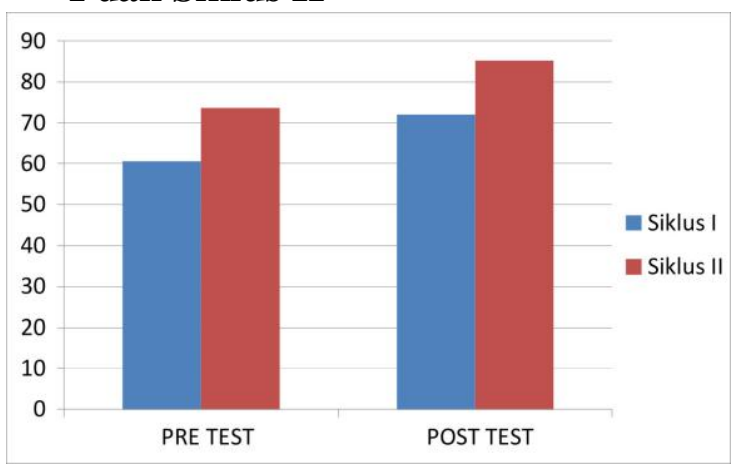

Berdasarkan grafik diatas, bahwa media adalah sarana yang dapat meningkatkan hasil belajar siswa. Dan ini diperkuat oleh teori yang dikemukakan Dina Indriana dalam bukunya yang berjudul Ragam Alat bantu media pembelajaran "Media juga dapat mempengaruhi proses belajar mengajar disekolah karena media merupakan alat bantu yang dapat digunakan sebagai penunjang proses belajar mengajar. Brown menyakini bahwa media yang digunakan dengan baik oleh guru atau siswa dapat mempengaruhi efektifitas program belajar dan mengajar".

\section{E. Kesimpulan}

Berdasarkan hasil penelitian dengan menerapkan media pembelajaran Pohon Klasifikasi terhadap hasil belajar IPS khususnya mata pelajaran Geografi, dapat disimpulkan bahwa penerapan media pembelajaran Pohon Klasifikasi dapat meningkatkan hasil belajar IPS khususnya mata pelajaran Geografi pada siswa kelas XI IIS B SMA Negeri 58 Jakarta. Pada siklus I dengan menggunakan media pembelajaran Pohon Klasifikasi dengan teknik metode pembelajaran yang bervariatif, hasil belajar siswa yang ditunjukkan pada nilai rata-rata pretest siklus I adalah 60,59 dengan nilai terendah
40 dan nilai tertinggi 80, sudah ada yang mencapai nilai KKM 75. Sedangkan nilai rata-rata postest siklus I adalah 72,05 dengan nilai terendah 55 dan nilai tertinggi 85. walaupun ada yang mencapai nilai 85 melebihi nilai KKM 75 namun masih ada siswa masih di bawah nilai KKM 75. Dan nilai rata-rata $N$-gain pada siklus I sebesar 0,28 (masuk dalam kelompok $N$-Gain rendah). Sedangkan pada penerapan media Pohon Klasifikasi dengan metode pembelajaran bervariatif pada siklus II mengalami peningakatan. Dengan nilai rata-rata pretest siklus II adalah 73,68 dengan nilai terendah 60 dan nilai tertinggi pretest 90, namun pada pretes siklus II masih ada siswa yang di bawah nilai KKM 75. Sedangkan pada nilai rata-rata postest siklus II adalah 85,29 dengan nilai terendah yaitu 75 dan nilai tertinggi postest mencapai 95. Di lihat dari hasil N-Gain yaitu sebesar 0,45 (masuk dalam kelompok $\mathrm{N}$-Gain Sedang). Dengan demikian pada siklus II ketuntasan hasil belajar mencapai $100 \%$ dari nilai KKM 75. Dari hasil penelitian yang dilakukan oleh peneliti, terdapat beberapa kelebihan dan kekurangan madia pembelajaran Pohon Klasifikasi. Diantaranya adalah sebagai berikut:

1. Kekurangan:

a. Murid masih bingung terhadap media pembelajaran Pohon Klasifikasi saat ditampilkan di depan kelas.

b. Materi yang ditampilkan media pembelajaran mind mapping hanyalah kata kunci saja.

c. Waktu yang agak lama untuk mencari dan mempelajari materimateri yang ingin dipelajari. 
2. Kelebihan:

a. Materi yang ditampilkan oleh guru di depan kelas berupa gambaran materi secara menyeluruh.

b. Membantu otak untuk mengingat, mengatur, membandingkan dan membuat materi yang behubungan satu dengan yang lain.

c. Memudahkan penambahan informasi baru.

d. Pengujian ulang menjadi lebih cepat, karena pokok materi yang dipelajari ada dalam media pembelajaran Pohon Klasifikasi.

\section{DAFTAR PUSTAKA}

David Yoga Hardiyanto, "Penerapan Mind Mapping Sebagai Media Dalam Meningkatkan Kemampuan Belajar IPA Pada Siswa Kelas IV SD Negeri 1 Sengre Kabupaten Pekalongan..", Skripsi Universitas Negeri Semarang, (Semarang, 2016)

Reni Tri Rahayu, "Meningkatkan Daya Ingat Melalui Penggunaan Media Mind Mapping Pada Anak Kelompok BI TK LKMD Sinosare Bangutapan.", Skripsi Universitas Negeri Yogyakarta, (Yogyakarta, 2014)

Wendri Wiratsiwi, "Pemanfaatan Media Pembelajaran Permainan Pohon Pintar Untuk Meningkatkan Hasil Belajar Pada Mata Pelajaran IPS Siswa Kelas IV Al-Hadad Singgahan Tuban.”, Skripsi Universitas Ranggolawe Tuban, (Tuban, 2016)

Arikunto, Suharsimi, Dasar-dasar Evaluasi Pendidikan, (Jakarta: Bumi Aksara, Ed. Revisi, Cet. 9, 2009.

Arikunto, Suharsimi, Prosedur Penilaian Suatu Pendekatan Praktik, Jakarta: PT. Rineka Cipta, Cet. 15, 2013.
Dirjen Pendidikan Islam, Undang-undang dan Peraturan Pemerintah RI Tentang Pendidikan, Jakarta: Depag, 2006.

Hermawan, Iwan, Geografi: Sebuah Pengantar, Bandung: Private Publishing, 2009.

Indriana, Dina, Ragam Alat Bantu Media Pengajaran, Jogjakarta: Diva Press, 2011.

Iskandarwassid dan Dadang Suhendar, Strategi Pembelajaran Bahasa, Bandung: PT Remaja Rosdakarya, Cet. 4, 2013.

Munadi, Yudhi, Media Pembelajaran; sebuah pendekatan baru, Jakarta: GP Press Group, Ed. Revisi, 2013.

Rudi Susilana dan Cepi Riyana, Media Pembelajaran: Hakikat Pengembangan, Pemanfaatan, dan Penilaian, Bandung: CV Wacana Prima, 2009.

Rusman, Belajar dan Pembelajaran Berbasis Komputer: Mengembangkan Profesionalisme Abad 21, Bandung: Alfabeta, 2013.

Sudirman, Arief S. (dkk), Media Pendidikan pengertian, pengembangan dan pemanfaatannya, Jakarta: RajaGraindo Persada, Cet. 1, 2010.

Sudjana, Nana, Penilaian Hasil Proses Belajar Mengajar, Bandung: Remaja Rosdakarya, Cet. 14, 2009.

Sudjana, Nana, Penilaian Hasil Proses Belajar Mengajar, Bandung: Remaja Rosdakarya, Cet. 17, 2012.

Sugiyono, Metode Penelitian Kuantitatif, Kualitatif, dan $R \& D$, Bandung: IKAPI, Cet. 8, 2009.

Suharsimi Arikunto, Suhardjono dan Supardi, Penelitian Tindakan Kelas, Jakarta: PT Bumi Aksara, Cet. 11, 2012.

Sukmadinata, Nana Syaodih, Landasan Psikologi Proses Pendidikan, Bandung: Remaja Rosdakarya, Cet. 4, 2007. 
Syah, Muhibbin, Psikologi Pendidikan dengan Pendekatan Baru, Bandung: PT. Remaja Rosda Karya, Cet. 19, 2014.

Syaiful Bahri Djamarah, Psikologi Belajar, Jakarta: PT. Rineka Cipta, Cet. 3, 2011.

Tim Kreatif LKM UNJ, Restorasi Pendidikan Indonesia: Menuju Masyarakat Terdidik Berbasis Budaya, Jogjakarta: Ar-Ruzz Media, 2011.
Tony Buzan, Buku Pintar Mund Map, Jakarta: PT. Gramedia Pustaka Utama, Cet. 6, 2008.

Trianto, Pengantar Pendidikan bagi Pengembangan Profesi Pendidikan dan Tenaga Kependidikan, Jakarta: Kencana, 2010. 
